\title{
MULTI-DECADAL FLUVIO-GEOMORPHOLOGICAL AND BANKLINE CHANGES OF THE GANGA RIVER AROUND BALLIA AND RUDRAPUR USING REMOTE SENSING AND GIS TECHNIQUES
}

\author{
Ami .J. Desai ${ }^{1}$, A.S. Arya ${ }^{2}$, and R.D. Shah ${ }^{1}$ \\ ${ }^{1}$ M.G. Science Institute, Geology Department and Space Applications Centre (ISRO), Ahmedabad-380015, India \\ ${ }^{2}$ Space Applications Centre, Indian Space Research Organization, Ahmedabad- 380015, India \\ Email: amiminaldesai@yahoo.co.in
}

KEY WORDS: Ganges, fluvio-geomorphology, bank-line changes, aggradation, degradation

\begin{abstract}
:
Fluvial landforms are developed due to river action and these processes help in understanding the development of various landforms on the earth's surface. Gangetic plain is vast alluvial tract made up of sand, silt and clay. This region receives heavy rainfall causing flash floods which results in bank-line shifting as well as various fluvio-geomorphological changes. Fluvial processes such as erosion and deposition not only play an important role in shaping of different fluvial landscapes but also contribute towards the braiding and meandering pattern which causes change in the flow pattern of the river channel. Transportation and deposition of the suspended load also contributes towards such changes. The present work describes various fluvio-geomorphological features and their changes during different time intervals in and around Ballia and Rudrapur. The paper also deals in understanding the problems like bank-line shifting, erosion and deposition caused by the continuous change in the fluvial patterns, bank erosion and sedimentation in this region over past 8 decades.
\end{abstract}

\section{INTRODUCTION}

Rivers play a major role in the economy of a country by sustaining agriculture, industry, energy generation and providing biological resources. The aim of the fluviogeomorphological studies is to describe and analyze different landforms, evolved due to the effect of flowing water and thereafter to develop an understanding of the ways in which the surface processes operate and control the development of these landforms (Gordon et al., 2004). Gangetic plain is the central part of foreland basin of Indo-Gangetic-Brahmaputra formed due to the collision of Indian and Eurasian plates during Eocene period (65 Ma) (Muley et al., 2006).

The basin is mainly comprised of Quaternary alluvium and is one of the largest alluvial tract of the world, where the major rivers like the Indus, Ganges and Brahmaputra deposit sand-silt sediments, forming a characteristic landscape. Ganges, is one of the largest rivers of the world and also the largest perennial river system amongst the 14 major rivers in India having its source in the Gangotri glacier in the Himalayas at an elevation of about $4200 \mathrm{~m}$ above mean sea level (msl). Two main rivers namely Alaknanda and Bhagirathi meet at Devprayag, and the confluence of these two rivers constitute the river Ganga. From Haridwar downwards it flows in the plains and passes through Uttar-Pradesh, Bihar, and West-Bengal and finally meets the Bay of Bengal traversing a total distance of about $2525 \mathrm{~km}$ (Arya et al., 2009).

Flowing water is an important parameter in the shaping up the earth's surface features. The river as it flows, due to the process of erosion carries lot of sediment load and deposits this load whenever the carrying capacity or the flow of the river decreases. The force of the flowing water is capable of cutting and eroding the rocks and the soils lying underneath and through this process the river shapes its landscape by either growing in size, forming a meandering pattern or sometimes merges with several smaller and bigger streams to form a network of braided channel. Rivers are important geomorphological agents showing great deal of diversity in form and behavior and also in transfer of water and sediment load from land surface to the oceans. Some of these landforms originate by denudational processes, some by erosional processes while some have their origin by the combination of many different processes (Leopold et al., 1995). Fluviogeomorphology focuses evolutionary process and also on the changing pattern of various geomorphic features such as floodplain, sand-bars, point-bars, river terraces, cut-off meanders, river channel, levees, ox-bow lakes, water-bodies, river islands, meander scars, palaeo meanders etc. and also tries to find out the reasons behind these changes.

Fluvial landforms are highly dynamic in nature and therefore synoptic view, repetitive coverage of the area, as well as stereo viewing capabilities of remote sensing has made it highly suitable for fluvio-geomorphological mapping. Different fluvial landforms depending on their dimensions can be easily identified through aerial and satellite remote sensing data (Gupta, 2003). Remote sensing satellites have a multi-temporal, multi-spectral and multi-spatial capability, due to which any long or short term changes can be easily detected. Synoptic view of the terrain features is also very helpful in obtaining valuable information (Rao, 2002). Indian remote sensing satellites such as IRS-1C,-1D and IRS-P6 (RESOURCESAT-1) have proved to be very helpful for carrying out river based studies. The present study emphasizes on the fluviogeomorphological changes and the bank-line shifting of the Ganga river near Ballia and Rudrapur using IRS-1 D LISS III multidate/multiseason remote sensing satellite data for the year 2000 and IRS-P6 (RESOURCESAT-1) for the year 2004 and 2006. The study for the year 2000 and 2004 was carried out on $1: 250,000$ scale whereas for 2006 it was done on 1:50,000 
scale. The comparative study was carried out using topographical maps.

\section{OBJECTIVES}

The main aim of the present study was to map and observe changes in bank-line, various fluvio-geomorphological features and estimation of erosion and deposition using multi-temporal satellite data over a period of around about 8 decades

\section{STUDY AREA}

Bihar is one of the most important places of East India and the most striking feature about Bihar is its network of river in which the Ganges is the most dominant one and is later joined by mighty tributaries like the Gandak, the Ghaghara, the Kosi, the Sone, the Punpun etc. Climatically, it experiences continental type of climate. The present study was confined from West of Ballia to the East of Chhapra covering Rudrapur. The entire region actually falls as part of U.P. - Bihar border. The Ganga river in this region exhibits a great deal of dynamicity thereby showing a continuous change in the river morphology as well as bank-line stability. The location map of the study area showing the river water course in that region is given in fig 1.

The latitude and longitude are as follows: Latitude: $25^{\circ} 0^{\circ} \mathrm{N}$ to $26^{\circ} 0^{\circ} \mathrm{N}$; Longitude: $84^{\circ} 0^{\circ} \mathrm{E}$ to $85^{\circ} 0^{\circ} \mathrm{E}$

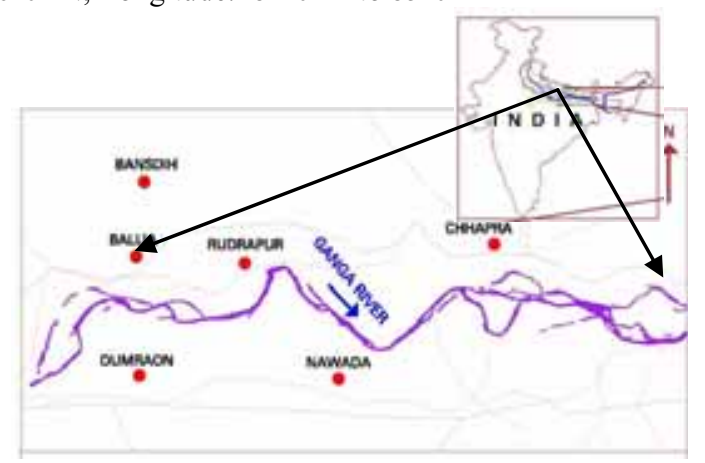

Figure 1: Location map of the study area

\section{DATA USED}

Digital multidate/multiseason IRS-1D LISS III satellite data for the year 2000 and RESOURCESAT P6 LISS III data for the year 2004 and 2006 both having a spatial resolution of $23.5 \mathrm{mt}$ were used to carry out the present study. The Survey of India (SOI) topographical maps of the year 1963 to1976 were used as the base reference maps. The specifications of the data used are given in table 1 .

\begin{tabular}{|c|c|c|c|c|}
\hline $\begin{array}{c}\text { Sr. } \\
\text { No }\end{array}$ & $\begin{array}{c}\text { Maps used and image } \\
\text { acquisition date and season }\end{array}$ & Year & Satellite & $\begin{array}{c}\text { Sensor } \\
\text { and } \\
\text { resolution }\end{array}$ \\
\hline 1 & $\begin{array}{c}\text { Topographic maps (base } \\
\text { reference maps) }\end{array}$ & $\begin{array}{c}1963- \\
1976\end{array}$ & - & - \\
\hline 2 & $\begin{array}{c}21 \text { mar00,15apr00 (pre- } \\
\text { monsoon)/26nov00,21 dec00 } \\
\text { (post-monsoon) }\end{array}$ & 2000 & IRS-1D & $\begin{array}{c}\text { LISS } \\
\text { III/23.5 } \\
\text { mt }\end{array}$ \\
\hline 3 & $\begin{array}{c}\text { 22apr04 (pre- } \\
\text { monsoon)/24nov04,18dec04 } \\
\text { (post-monsoon) }\end{array}$ & 2004 & IRS-P6 & $\begin{array}{c}\text { LISS } \\
\text { III/23.5 } \\
\text { mt }\end{array}$ \\
\hline 4 & $\begin{array}{l}19 / \text { mar/06 (pre-monsoon) } \\
\text { (post- } \\
\text { (pre- }\end{array}$ & 2006 & IRS-P6 & $\begin{array}{c}\mathrm{LISS} \\
\text { monsoon) } 24 / \text { mar/06 } \\
\text { mons. }\end{array}$ \\
\hline
\end{tabular}

\begin{tabular}{|l|l|l|l|l|}
\hline $\begin{array}{l}\text { monsoon) } \\
13 / \text { dec/06 (post-monsoon) }\end{array}$ & & & \\
\hline
\end{tabular}

\section{METHODOLOGY}

For carrying out the interpretation of various fluviogeomorphological features and to understand the river behavior, a comparative study was carried out using multidate/multiseason IRS satellite data and GIS. First of all, in order to minimize the errors in mapping, registration of the satellite data was carried out with reference to the ground coordinates of the topographic maps. The topographic maps were taken as the base reference and the database was generated representing different fluvial features. Various linear features such as roads, railway and settlements were also demarcated. Different thematic layers such as river channel, river bank-line, flood-plain, point-bars, sand-bars, palaeo-meanders, levees, river islands, water-bodies and ox-bow lakes were demarcated on the 2000, 2004 and 2006 satellite data using ERDAS, 8.5 image processing software. All these layers were then compiled to form fluvio-geomorphological map on 1:250,000 scale for the year 2000 and 2004 and on 1:50,000 scale for the year 2006. Different parameters such as river pattern, shift in the river channel, length of the river bank, length of the surface water channel, surface water area of the river, area of the floodplains, sand-bar area, width of the river and the area of the island were calculated for both pre-monsoon as well as postmonsoon data. This was followed by the integration of fluviogeomorphological data interpreted using the satellite data. The river channel changes and the morphological changes were studied by comparing and superimposing the SOI topographical maps and the satellite images.

\section{RESULTS AND DISCUSSION}

The results regarding the bank-line changes, amount of erosion/deposition and fluvio-geomorphological changes obtained from the study are discussed below:

\subsection{Bankline changes}

Detailed mapping of the water course and river banks in this region on SOI maps and the post-monsoon IRS satellite data of 2000, 2004 and 2006 showed prominent, distinct shifting at various locations between the years 1963-'76 to 2006 as shown in fig 2. The shift is mainly in the South and South-East and North and North-West direction. Near Ballia, the shift is mainly in the Southern direction by around $1-3 \mathrm{~km}$, whereas towards little West of Ballia the river shows a Northward shift. Again near Dumraon, the river shows a prominent change towards the South and South-East direction. Maximum change has been observed near Rudrapur where the river has showed a major shift of around 3-5 km in the Southern and the Eastern direction. Moving towards East from Rudrapur, near Chhapra and West of Chhapra the river shows shifting towards the Southern direction. Overall it can be said that the region has undergone a major bank-line change ranging from 1-5 km and the shift direction is mainly in the South and Southeast.

\subsection{Erosion and deposition along both the bank-lines}

A detailed mapping regarding the area under aggradation and degradation showed that both the bank-lines in this region has undergone aggradation as well as degradation with a varying amount. From fig 3, it can be seen that the Northern or the left bank has undergone much more aggradation then degradation 
which indicates the shrinking of the river bed whereas conversely the Southern bank shows much more degradation then aggradation which indicates the widening of the river bed. Amount of sediment deposition is much higher near Ballia and Rudrapur where the shifting of the bank-lines towards the Southern direction is also very prominent. The region near Ballia and Rudrapur has shown more aggradation then degradation on both the banks. On the Southern bank near Dumraon, the river has undergone erosion as well as deposition and the shifting of the river channel has occurred mainly in the East and South-East direction. Near Nawada, the Southern bank shows very prominent degradation and the Northern bank has also comparatively undergone more degradation then aggradation.

\subsection{Fluvio-geomorphological changes}

Various fluvio-geomorphological were interpreted from the IRS data. Presence of ox-bow lakes and numerous water-bodies near Dumraon and Nawada suggest and indicate the remnants of the old Ganga river course refer fig 4 (a-g). Near Rudrapur, the river channel shows a sharp meandering pattern refer fig 5(a). This pattern is also seen during 1963-'76 but it is less prominent then compared to 20002004 and 2006. Such sharp meandering pattern suggests that the river may be controlled by some basement structure like fault or fracture in that region. The river shows braided pattern at places near Ballia and West of Ballia, which is prominently visible in 2000, 2004 and 2006 whereas it is less prominent during 1963-'76. Near Chhapra and East of Chhapra this pattern is seen throughout all the years. A detailed statistical data of different parameters such as length of river bank, area of sand-bars, flood-plain, islands, width of the river bank, surface water area of the river, type of river pattern etc was calculated and studied. From this a comparative study was carried out from which the amount of changes occurred were studied and a complete past and present fluvial scenario was established. For details refer table (1\&2).

\section{CONCLUSIONS}

- The present study showed prominent changes in river bank-line as well as various fluvial features. It showed great deal of variation in direction, dimension and magnitude. Presence of ox-bow lakes near Dumraon and Nawada as well as the presence of numerous small and large water-bodies suggest and indicate the remnants of the old Ganga river course.

- The shifting of the river channel in this region is mainly due to the erosional and depositional processes of the river. The overall direction of shifting is in the South and South-East direction.

- Near Rudrapur the river channel shows a sharp meandering pattern which suggests that the river may be controlled by some basement structure like fault or fracture in that region.

- The river shows braided pattern at places near Ballia and West of Ballia. This type of pattern usually suggests that the river channel is incapable of carrying any further sediment load.

- The region shows prominent shifting at various locations. Near Ballia, the shift is around 1-3 km, whereas maximum shift in this region was found near Rudrapur by about 3-5 $\mathrm{km}$ in the Southern and Eastern direction.

- Northern bank has undergone much more aggradation then degradation which indicate shrinking of the river bed whereas the Southern bank shows much more degradation then aggradation which indicate widening of the river bed. Amount of erosion and deposition near Ballia in 2006 was estimated to be $23.0 \mathrm{sq} \mathrm{km}$ and $56.0 \mathrm{sq} \mathrm{km}$ whereas near Rudrapur the amount of erosion and deposition was 29.0 sq $\mathrm{km}$ and $82.0 \mathrm{sq} \mathrm{km}$ respectively.

\begin{tabular}{|c|c|c|c|c|c|}
\hline \multirow[t]{2}{*}{$\begin{array}{l}\mathrm{Sr} \\
\text { no }\end{array}$} & \multirow{2}{*}{$\begin{array}{c}\text { Features } \\
\text { (region covering regions in and } \\
\text { around Ballia and Rudrapur) }\end{array}$} & \multicolumn{2}{|c|}{$\begin{array}{c}\text { Observations from pre-monsoon } \\
\text { satellite data }\end{array}$} & \multicolumn{2}{|c|}{$\begin{array}{l}\text { Observations from post- } \\
\text { monsoon satellite data }\end{array}$} \\
\hline & & $\begin{array}{c}2000 \\
\text { pre-monsoon } \\
\text { data }\end{array}$ & $\begin{array}{c}2000 \\
\text { post-monsoon } \\
\text { data }\end{array}$ & $\begin{array}{l}2004 \text { pre- } \\
\text { monsoon data }\end{array}$ & $\begin{array}{c}2004 \text { post- } \\
\text { monsoon data }\end{array}$ \\
\hline 1 & $\begin{array}{l}\text { Geomorphological } \\
\text { features }\end{array}$ & \multicolumn{2}{|c|}{$\begin{array}{l}\text { River with water, sandbars, } \\
\text { island, agriculture, } \\
\text { water bodies, flood plain, ox- } \\
\text { bow lakes }\end{array}$} & \multicolumn{2}{|c|}{$\begin{array}{l}\text { River with water, sandbars, } \\
\text { island, agriculture, } \\
\text { water bodies, flood plain, ox- } \\
\text { bow lakes }\end{array}$} \\
\hline 2 & River pattern & \multicolumn{2}{|c|}{$\begin{array}{l}\text { Braided and complex } \\
\text { asymmetrical meandering }\end{array}$} & \multicolumn{2}{|c|}{$\begin{array}{l}\text { Braided and complex } \\
\text { asymmetrical meandering }\end{array}$} \\
\hline 3 & $\begin{array}{l}\text { Shifting of the river } \\
\text { Channel }\end{array}$ & \multicolumn{2}{|c|}{$\begin{array}{l}\text { Distinct up to } 1-2 \mathrm{~km} \text { in Ballia } \\
\text { and } 1-3 \mathrm{~km} \text { in Rudrapur }\end{array}$} & \multicolumn{2}{|c|}{$\begin{array}{l}\text { Distinct up to } 1-2.5 \mathrm{~km} \text { in Ballia } \\
\text { and 2-4 km in Rudrapur }\end{array}$} \\
\hline 4 & Length of the river bank & \multicolumn{4}{|c|}{$134.00 \mathrm{~km}$} \\
\hline 5 & Surface water area of the river & $100.00 \mathrm{sq} \mathrm{km}$ & $150.00 \mathrm{sq} \mathrm{km}$ & $87.00 \mathrm{sq} \mathrm{km}$ & $121.00 \mathrm{sq} \mathrm{km}$ \\
\hline 6 & Area of the sandbars & $183.00 \mathrm{sq} \mathrm{km}$ & $165.00 \mathrm{sq} \mathrm{km}$ & $152 \mathrm{sq} \mathrm{km}$ & $147.00 \mathrm{sq} \mathrm{km}$ \\
\hline 7 & Area of the flood plain & $710.00 \mathrm{sq} \mathrm{km}$ & $751.00 \mathrm{sq} \mathrm{km}$ & $708.00 \mathrm{sq} \mathrm{km}$ & $760.00 \mathrm{sq} \mathrm{km}$ \\
\hline 8 & Width of the river & $\begin{array}{l}\text { From } 1.0 \mathrm{~km} \\
\text { to } 9.0 \mathrm{~km}\end{array}$ & $\begin{array}{l}\text { From } 1.0 \mathrm{~km} \\
\text { to } 9.5 \mathrm{~km}\end{array}$ & $\begin{array}{l}\text { From } 0.8 \mathrm{~km} \\
\text { to } 9.4 \mathrm{~km}\end{array}$ & $\begin{array}{c}\text { From } 0.8 \mathrm{~km} \\
\text { to } 10.3 \mathrm{~km}\end{array}$ \\
\hline 9 & Area of the island & $91.00 \mathrm{sq} \mathrm{km}$ & $92.00 \mathrm{sq} \mathrm{km}$ & $118.00 \mathrm{sq} \mathrm{km}$ & $131.00 \mathrm{sq} \mathrm{km}$ \\
\hline
\end{tabular}

Table 1: Fluvial changes during 2000 and 2004 
ISPRS Archives XXXVIII- 8/W20; Workshop Proceedings: Earth Observation for Terrestrial Ecosystems

\begin{tabular}{|c|c|c|c|c|c|}
\hline $\begin{array}{l}\text { Sr. } \\
\text { No. }\end{array}$ & $\begin{array}{l}\text { Morphological } \\
\text { features }\end{array}$ & $\begin{array}{c}\text { Observations } \\
\text { near Ballia from } \\
2006 \text { pre- } \\
\text { monsoon satellite } \\
\text { data } \\
\end{array}$ & $\begin{array}{c}\text { Observations } \\
\text { near Ballia from } \\
2006 \text { post- } \\
\text { monsoon satellite } \\
\text { data } \\
\end{array}$ & $\begin{array}{c}\text { Observations } \\
\text { near Rudrapur } \\
\text { from } 2006 \text { pre- } \\
\text { monsoon satellite } \\
\text { data } \\
\end{array}$ & $\begin{array}{l}\text { Observations near } \\
\text { Rudrapur from } \\
2006 \text { post- } \\
\text { monsoon satellite } \\
\text { data }\end{array}$ \\
\hline 1 & $\begin{array}{l}\text { Geomorphological } \\
\text { features }\end{array}$ & $\begin{array}{l}\text { River with water, } \\
\text { sandbars, island, } \\
\text { grass/agriculture, } \\
\text { lakes, ox-bow } \\
\text { lakes floodplain }\end{array}$ & $\begin{array}{l}\text { River with water, } \\
\text { sandbars, island, } \\
\text { grass/agriculture, } \\
\text { lakes, ox-bow } \\
\text { lakes floodplain }\end{array}$ & $\begin{array}{l}\text { River with water, } \\
\text { sandbars, island, } \\
\text { grass/agriculture, } \\
\text { floodplain }\end{array}$ & $\begin{array}{l}\text { River with water, } \\
\text { sandbars, island, } \\
\text { grass/agriculture, } \\
\text { floodplain }\end{array}$ \\
\hline 2 & River pattern & $\begin{array}{c}\text { Typical complex } \\
\text { asymmetrical } \\
\text { meandering }\end{array}$ & $\begin{array}{c}\text { Typical complex } \\
\text { asymmetrical } \\
\text { meandering }\end{array}$ & $\begin{array}{c}\text { Typical complex } \\
\text { asymmetrical } \\
\text { meandering }\end{array}$ & $\begin{array}{c}\text { Typical complex } \\
\text { asymmetrical } \\
\text { meandering }\end{array}$ \\
\hline 3 & $\begin{array}{l}\text { Shifting of the } \\
\text { river channel }\end{array}$ & $\begin{array}{c}\text { Shifting of the } \\
\text { river towards N } \\
\text { and SE about 1-2 } \\
\text { km }\end{array}$ & $\begin{array}{c}\text { Shifting of the } \\
\text { river towards } \mathrm{N} \\
\text { and SE } \\
\text { Maximum about } \\
1-3 \mathrm{~km}\end{array}$ & $\begin{array}{l}\text { Distinct and up } \\
\text { to } 4 \mathrm{~km} \text { in the } \mathrm{S} \\
\text { direction }\end{array}$ & $\begin{array}{l}\text { About } 2-5 \mathrm{~km} \\
\text { towards the } \mathrm{S} \\
\text { direction }\end{array}$ \\
\hline 4 & $\begin{array}{c}\text { Length of the river } \\
\text { bank }\end{array}$ & \multicolumn{2}{|c|}{$45.00 \mathrm{~km}$} & \multicolumn{2}{|c|}{$55 \mathrm{~km}$} \\
\hline 5 & $\begin{array}{c}\text { Surface water area } \\
\text { of the river }\end{array}$ & $21.00 \mathrm{sq} \mathrm{km}$ & $29.00 \mathrm{sq} \mathrm{km}$ & $28.00 \mathrm{sq} \mathrm{km}$ & $36.00 \mathrm{sq} \mathrm{km}$ \\
\hline 6 & $\begin{array}{l}\text { Area of the } \\
\text { sandbars }\end{array}$ & $52.00 \mathrm{sq} \mathrm{km}$ & $43.00 \mathrm{sq} \mathrm{km}$ & $49.00 \mathrm{sq} \mathrm{km}$ & $35.00 \mathrm{sq} \mathrm{km}$ \\
\hline 7 & $\begin{array}{l}\text { Area of the } \\
\text { floodplain }\end{array}$ & 260.00. sq km & $267.00 \mathrm{sq} \mathrm{km}$ & $390.00 \mathrm{sq} \mathrm{km}$ & $384.00 \mathrm{sq} \mathrm{km}$ \\
\hline 8 & Width of the river & $\begin{array}{c}\text { From } 1.3 \mathrm{~km} \text { to } \\
5.0 \mathrm{~km}\end{array}$ & $\begin{array}{l}\text { From } 1.0 \mathrm{~km} \text { to } \\
5.7 \mathrm{~km}\end{array}$ & $\begin{array}{l}\text { From } 1.0 \mathrm{~km} \text { to } \\
4.6 \mathrm{~km}\end{array}$ & $\begin{array}{c}\text { From } 0.6 \mathrm{~km} \text { to } \\
3.5 \mathrm{~km}\end{array}$ \\
\hline 9 & Area of the island & $8.00 \mathrm{sq} \mathrm{km}$ & $40.00 \mathrm{sq} \mathrm{km}$ & $7.00 \mathrm{sq} \mathrm{km}$ & $7.00 \mathrm{sq} \mathrm{km}$ \\
\hline
\end{tabular}

Table 2: Fluvial changes during 2006

\section{REFERENCES}

Arya AS, Shah RD, Muley MV, Desai A and Desai J (2009) Atlas on Fluvial Geomorphology of the Ganga river in Bihar, based on satellite and field observations, Atlas, IV, SAC/RESA/MESG/ESHD/ATLAS/69/ 2009, pp. 3.

Gordon ND, Mc Mahon TA, Finlayson BL, Gippel CJ and Nathan RJ (2004) Stream hydrology: an introduction for ecologists, ( $2^{\text {nd }}$ edit), Wiley publications, $267 \mathrm{p}$

Gupta RP (2003) Remote Sensing Geology, ( $2^{\text {nd }}$ edit), Springer, $435-439 p$

Leopold LB, Wolman MG and Miller JP (1995) Fluvial Processes in Geomorphology, ( $2^{\text {nd }}$ edit), Dover publications, INC, New York, $3 \mathrm{p}$.
Muley MV, Shah RD, Desai A and Desai J (2006) Atlas on Fluvial Geomorphology of the Ganga river in Bihar, based on satellite data, Atlas, II, Report,. SAC/RESIPA/MWRG/ESHD/PR/57/2006, pp 2.

Rao DP (2002) Remote sensing application in geomorphology, International Society for Tropical Ecology, 43 (1): 49-59.

\section{ACKNOWLEDGEMENTS}

The authors are thankful to Dr. R.R. Navalgund, Director, Space Applications Centre (SAC) and Dr. B.K. Jain, Principal M.G. Science Institute, for their encouragement and support. We are grateful to Dr. J.S. Parihar, Mission Director, EOAM and Dr. Ajai, Group Director, MPSG/PMD, SAC, for providing all necessary support and guidance. 


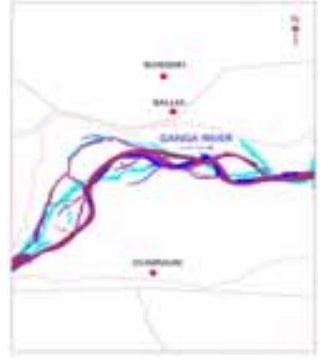

a)

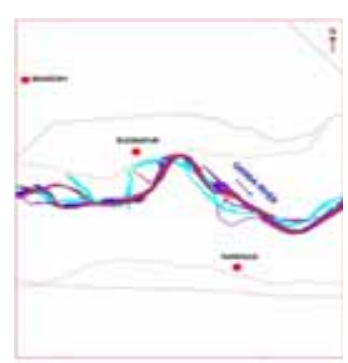

b)

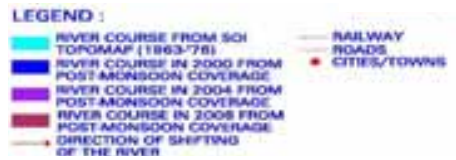

Fig 2: Shifting of the river channel a) near Ballia b) near Rudrapur

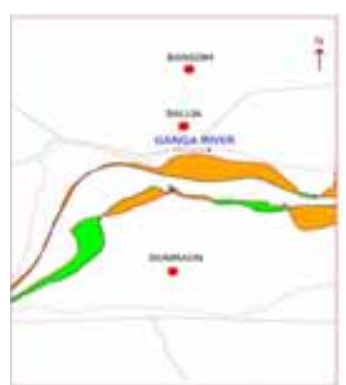

a)

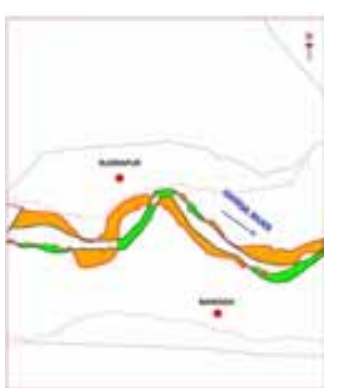

b)
LERENO

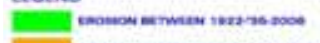

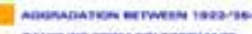

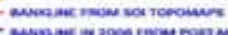
mavis

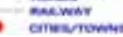

Fig 3: Erosion and deposition along both the banks of the Ganga river near a) Ballia b) near Rudrapur

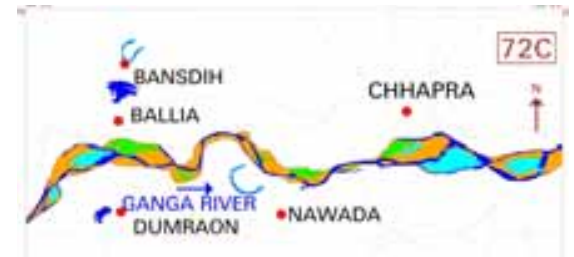

Fig 4 (a): Fluvial features as demarcated from SOI maps

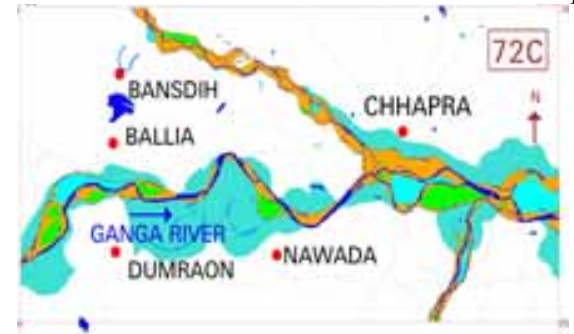

Fig 4 (b): Fluvial features as demarcated from 2000 premonsoon satellite data

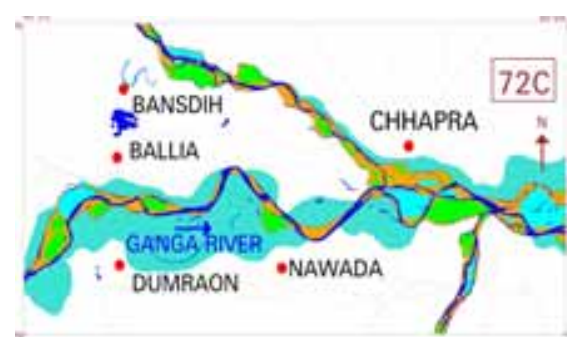

Fig 4 (c): Fluvial features as demarcated from 2000 postmonsoon satellite data

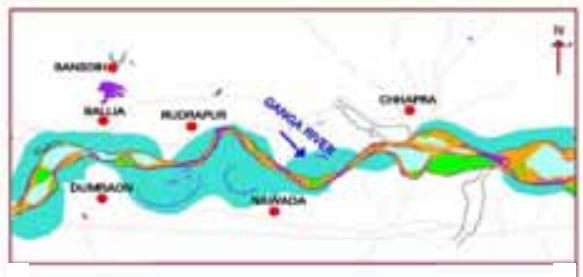

Fig 4 (d): Fluvial features as demarcated from 2004 premonsoon satellite data

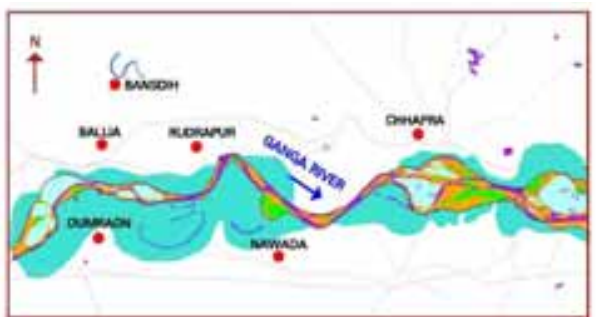

Fig 4 (e): Fluvial features as demarcated from 2004 postmonsoon satellite data

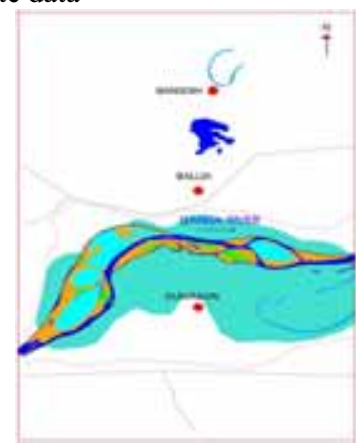

Fig 4 (f): Fluvial features as demarcated from 2006 premonsoon satellite data near Ballia

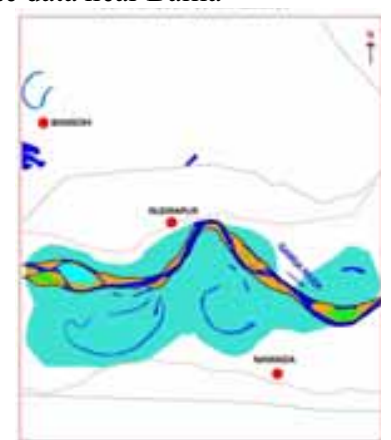

Fig 4 (g): Fluvial features as demarcated from 2006 premonsoon satellite data near Rudrapur 